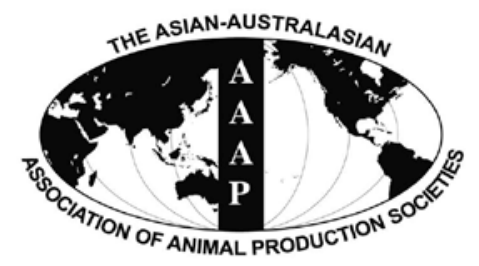

Asian-Aust. J. Anim. Sci.

Vol. 25, No. 2 : 213 - 223

February 2012

www.ajas.info

http://dx.doi.org/10.5713/ajas.2011.11186

\title{
Effect of Total Mixed Ration with Fermented Feed on Ruminal In vitro Fermentation, Growth Performance and Blood Characteristics of Hanwoo Steers
}

\author{
S. H. Kim ${ }^{1}$, M. J. Alam ${ }^{1,2}$, M. J. Gu ${ }^{1}$, K. W. Park ${ }^{1}$, C. O. Jeon ${ }^{3}$, Jong K. Ha ${ }^{4}$, K. K. Cho ${ }^{5}$ and S. S. Lee ${ }^{1, *}$ \\ ${ }^{1}$ Ruminant Nutrition and Anaerobe Laboratory, Department of Animal Science and Technology, \\ Sunchon National University, Suncheon, Jeonnam 540-742, Korea
}

\begin{abstract}
In this study, two experiments were conducted to evaluate the total mixed ration with fermented feed (TMRF) and total mixed ration (TMR) by rumen in vitro fermentation and their effects on the growth performance and blood characteristics of Hanwoo steers. In experiment 1 , three Hanwoo steers $(600 \pm 47 \mathrm{~kg})$, each permanently fitted with a ruminal cannula were used. In this experiment, three diets designated as T1, TMRF (18.4\% fermented feed, tall fescue, mammoth wild rye forage and whole crop barley); T2, TMRF (17.7\% fermented feed, rice straw and whole crop barley); and T3, TMR (rice straw, whole crop barley and probiotics, but no fermented feed), which were subjected to rumen in vitro fermentation for $48 \mathrm{~h}$. The results demonstrated that DM disappearance rate gradually increased with advancing fermentation time, but T1 and T2 were higher than the T3 $(\mathrm{p}<0.05)$ from $3 \mathrm{~h}$ to $12 \mathrm{~h}$, but insignificant $(\mathrm{p}>0.05)$ at 24 and $48 \mathrm{~h}$. None of the specific VFAs were affected except for acetic and non volatile lactic acids, which were produced more in T2 than in T1 and T3 at $24 \mathrm{~h}$ and $48 \mathrm{~h}$ of incubation. A/P was lower in T1 and T2 than inT3 at $24 \mathrm{~h}(\mathrm{p}<0.05)$ and $48 \mathrm{~h}(\mathrm{p}>0.05)$ of incubation. These results confirmed that TMRF-related treatment shows a superior performance to that of TMR during the ruminal fermentation period. In experiment 2, the three diets in experiment 1 plus 1 more control diet (concentrates, probiotics and 2\% rice straw of body weight) were fed to the 48 Hanwoo steers $(160 \pm 10 \mathrm{~kg}$ ) for a period of $168 \mathrm{~d}$. The results demonstrated that the daily and total live weight gain and feed efficiency were higher $(\mathrm{p}<0.05)$ in the TMRF and TMR groups than in the control group. SGOT, SGPT and BUN $(\mathrm{p}<0.05)$ were reduced in TMRF relative to the control and TMR groups by $168 \mathrm{~d}$ which confirmed that TMRF shows better blood profiles than the TMR and control groups. Overall, these results appear to show that TMRF has better in vitro ruminal characteristics than those of TMR; growth performance and blood profiles were also found to be superior in TMRF than in the TMR and control groups. Thus, our findings suggest that TMRF-based feed supplies are favorable for Hanwoo cattle. (Key Words : Blood Profiles, Fermented Feed, Growth Performance, Hanwoo, Rumen Fermentation, TMR)
\end{abstract}

\section{INTRODUCTION}

The cost of feed production is rising in the livestock husbandry industry, owing largely to dietary dependency on

\footnotetext{
* Corresponding Author : Sang-Suk Lee. Tel: +82-61-750-3237, E-mail: rumen@scnu.kr

${ }^{2}$ Dept. of Animal Science, Sher-e-Bangla Agricultural University, Dhaka-1207, Bangladesh.

${ }^{3}$ Dept. of Life Science, Chung-Ang University, Seoul 156-756, Korea.

${ }^{4}$ Depart. of Agricultural Biotechnology and Research Institute for Agriculture and Life Sciences, College of Agriculture and Life Sciences, Seoul National University, Seoul 151-742, Korea.

${ }^{5}$ Dept. of Animal Resources Technology, Gyeongnam National University of Science and Technology, Chinju 660-758, Korea.

Received June 20, 2011; Accepted September 1, 2011
}

raw material. New feeding habits and strategies employing different roughages are clearly necessary to overcome the problem. The total mixed ration (TMR) has been the subject of great interest from farmers because of its expected benefits in the nutrition, management and production of ruminant animals (Owen, 1984; Howard et al., 1986; Sirohi et al., 2001). Farmers raising homebred fattening cattle are showing increased interest in fibroid material assorted feed, such as the TMR allowance, over concentrates (Kim et al., 2003), because homebred fattening cattle (rapid growing) require more feed intake for rapid body weight gain. It has already been experimentally confirmed that fibroid materials assorted feed is advantageous in maintaining the homeostasis of ruminant stomach $\mathrm{pH}$, reducing the incidence of metabolic disease, and improving milk production (Nock et al., 1986; Harrison et al., 1989; 
Kellems et al., 991). In recent years, the expediency of feeding cattle a TMR has become widely accepted. The benefits of a TMR include increased feed intake, enhanced use of low-cost alternative feed ingredients, ability to control the forage concentrate ratio, lower incidence of metabolic and digestive disorders, and reduced labor input for feeding (Owen, 1984). TMR is a proper type of feed especially when agricultural by-products with high moisture are to be included (Li et al., 2003). Silage, forage, and hay are the conventional roughages contained in TMR (Chumpawadee and Pimpa, 2009). Including fermented feed in TMR may change its digestibility as well as feed efficiency. However, there is no available information about TMR prepared with fermented feed. Moreover, tall fescue is an imported feed ingredient usually used to prepare TMR, but the use of domestic straw and whole barley, available in Korea, to replace the tall fescue may reduce the feeding cost.

There is currently insufficient information regarding TMR prepared by replacing tall fescue with domestic rice straw and whole barley with fermented feed (TMRF) and its effects on cattle. The principal objective of this study was to evaluate the effects of different TMR with fermented feed over simple TMR on Hanwoo steers.

\section{MATERIALS AND METHODS}

\section{Experimental feeds and treatments}

The total mixed feed was formulated on the basis of standard tables of feed composition in the Korean NIAS (2007). Treatment 1 (TMRF) contained 18.4\% fermented feed with TMR (tall fescue, mammoth wild rye forage (Leymus racemosus), whole barley etc.). Treatment 2 (TMRF) contained $17.9 \%$ fermented feed with TMR (rice straw, whole barley etc.). Treatment 3 (TMR) contained rice straw, whole barley and probiotics, but no fermented feed added. Control contained available concentrates and probiotics. Probiotics used in the diets were prepared using Lactobacillus acidophilus (KCTC3140) and Saccharomyces cerevisiae (KACC30068), which were sourced from the Korean collection for type culture, Daejeon, Korea. The details of ingredients and composition of the different treatments are provided in Table 1 . The chemical compositions were analyzed according to the guidelines of the AOAC (1995). NDF and ADF were analyzed with an Ankom fiber analyzer (ANKOM Tech. Corp, Fairport, NY) based on Van Soest's method (Van Soest et al., 1991).

Fermented feed was prepared for T1 and T2 with rice bran and wheat bran $(50 / 50 \mathrm{w} / \mathrm{w})$ supplemented with $0.1 \%$ Lactobacillus acidophilus KCTC3140 $\left(1.2 \times 10^{7} \mathrm{CFU} / \mathrm{ml}\right)$ and $0.1 \%$ Saccharomyces cerevisiae KACC30068 $\left(2.1 \times 10^{6}\right.$ $\mathrm{CFU} / \mathrm{ml}$ ); it was then appropriately mixed and maintained at the optimal temperature of $37^{\circ} \mathrm{C}$ for $48 \mathrm{~h}$ to achieve proper fermentation in the confined condition. Finally, these
Table 1. Ingredient and chemical composition of the experimental diets for Exp. 2

\begin{tabular}{|c|c|c|c|c|}
\hline & \multicolumn{4}{|c|}{ Treatments } \\
\hline & Con $^{1}$ & $\mathrm{~T} 1^{2}$ & $\mathrm{~T} 2^{3}$ & $\mathrm{~T}^{4}$ \\
\hline \multicolumn{5}{|l|}{ Diet ingredients (\%) } \\
\hline Beet pulp & - & - & 9.5 & 8.5 \\
\hline Brewer grain & 19.0 & - & - & - \\
\hline Calcium sulfate & 0.26 & - & - & - \\
\hline Wheat & 6.5 & - & - & - \\
\hline Tapioca & 5.5 & - & - & - \\
\hline Corn $(\mathrm{M})^{5}$ & 6.9 & 0.8 & - & - \\
\hline Corn $(F)^{6}$ & 26.47 & 5.1 & 4.0 & 4.3 \\
\hline Fermented mixture $^{7}$ & - & 18.4 & 17.7 & - \\
\hline Mammoth wild rye forage & - & 7.2 & - & - \\
\hline Lime stone & 1.52 & 0.65 & 0.8 & 0.9 \\
\hline Malt hulls & 1.5 & - & - & 8.5 \\
\hline Mineral mixture ${ }^{8}$ & 0.25 & - & - & - \\
\hline Vitamin premix $^{9}$ & 0.35 & 0.35 & 0.35 & 0.1 \\
\hline Molasses & 0.65 & 5.1 & 5.5 & 6.0 \\
\hline Probiotics & 0.2 & - & - & 0.1 \\
\hline Rice bran & - & 24.5 & 19.0 & 20.5 \\
\hline Rice straw & - & - & 7.9 & 8.5 \\
\hline Salt & 0.6 & - & - & - \\
\hline Tall fescue & - & 7.2 & - & - \\
\hline Concentrate mixture ${ }^{10}$ & 30.3 & - & - & - \\
\hline Whole crop barley & - & 25.6 & 35.6 & 42.7 \\
\hline Water & - & 5.1 & - & - \\
\hline \multicolumn{5}{|c|}{ Chemical composition of mixed feeds } \\
\hline $\mathrm{DM}(\%)$ at $105^{\circ} \mathrm{C}$ & 87.0 & 64.0 & 64.0 & 65.0 \\
\hline $\mathrm{TDN}^{11}$ & 69.0 & 69.0 & 69.0 & 69.0 \\
\hline Crude protein & 14.0 & 13.0 & 12.0 & 12.0 \\
\hline Crude fiber & 18.0 & 17.0 & 17.0 & 16.0 \\
\hline $\mathrm{ADF}^{12}$ & - & 24.0 & 24.0 & 22.0 \\
\hline $\mathrm{NDF}^{13}$ & - & 44.0 & 45.0 & 45.0 \\
\hline Calcium & 0.8 & 1.12 & 0.98 & 0.95 \\
\hline Phosphorus & 0.12 & 0.39 & 0.34 & 0.42 \\
\hline
\end{tabular}

${ }^{1}$ As usual mixed diet.

${ }^{2}$ Tall fescue, $184 \mathrm{~g} / \mathrm{kg}$ fermented feed, mammoth wild rye forage, whole barley forage etc.

${ }^{3}$ Rice straw, $177 \mathrm{~g} / \mathrm{kg}$ fermented feed, whole barley forage etc.

${ }^{4}$ Rice straw, probiotics, whole barley forage etc.

${ }^{5}$ Corn meal. ${ }^{6}$ Corn Flake.

${ }^{7}$ Rice bran $50 \%$ and wheat bran $50 \%(\mathrm{w} / \mathrm{w})$ with $0.1 \%$ Lactobacillus acidophilus KCTC3140 $\left(1.2 \times 10^{7} \mathrm{CFU} / \mathrm{ml}\right)$ and $0.1 \%$ Saccharomyces cerevisiae KACC30068 $\left(2.1 \times 10^{6} \mathrm{CFU} / \mathrm{ml}\right)$ were mixed and maintained at the optimal temperature for fermentation.

${ }^{8}$ Guaranteed analysis: $360 \mathrm{~g} / \mathrm{kg} \mathrm{Na}, 600 \mathrm{~g} / \mathrm{kg} \mathrm{Cl}, 1,600 \mathrm{mg} / \mathrm{kg} \mathrm{Fe}, 5,000$ $\mathrm{mg} / \mathrm{kg} \mathrm{Mn,} \mathrm{7,500} \mathrm{mg/kg} \mathrm{Zn,} \mathrm{2,500} \mathrm{mg/kg} \mathrm{Cu,} 70 \mathrm{mg} / \mathrm{kg} \mathrm{I}$, and $40 \mathrm{mg} / \mathrm{kg}$ Co (Shur-Gain Feeds Inc., Moncton, New Brunswick, Canada).

${ }^{9}$ Guaranteed analysis: 10,000,000 IU/kg vitamin A, 1,500,000 IU/kg vitamin D and 15,000 IU/kg vitamin E (Shur-Gain Feeds Inc., Moncton, New Brunswick, Canada).

${ }^{10}$ Mixture of $23.64 \%$ wheat meal, 28\% corn meal, $19 \%$ oil seed meal, $7 \%$ coconut meal and $22.36 \%$ palm meal from Hanwoo TMR feed factory, Ziri-mountain, Sunhan, Jeonnam, Korea.

${ }^{11}$ total digestible nutrient. ${ }^{12}$ Acid detergent fiber.

${ }^{13}$ Neutral detergent fiber. 
fermented feeds were stored outside for $24 \mathrm{~h}$ to achieve normal conditions. The chemical composition of the fermented feed contained DM, CP, CF, ADF and NDF were $59.0 \%, 8.8 \%, 8.4 \%, 13.2 \%$ and $22.4 \%$, respectively.

\section{Animals, management and experimental procedure}

Experiment 1 - For in vitro model : Exp. 1 used only T1, T2 and T3. Rumen fluids were pooled from 3 ruminallycannulated Hanwoo steers of 24 months of age and body weights of $600 \pm 47 \mathrm{~kg}$. The collected fluids were filtered through 4-folded cheese cloth and contained in glass bottles that were placed in a water bath for $1 \mathrm{~h}$ at a temperature of $39^{\circ} \mathrm{C}$. A vacuum pump was used to remove the upper residue and the middle rumen fluids were collected for experimental use. Constant $\mathrm{CO}_{2}$ gas flow was used to mix the rumen fluid with media and to fill the serum bottles under anaerobic conditions. Particle-free rumen fluid as an inoculums was anaerobically transferred $(20 \% \mathrm{v} / \mathrm{v})$ to a medium ( $\mathrm{pH}$ 6.7) containing different minerals, in accordance with the method described by Russell and Vansoest (1984); Russell and Strobel (1988). Subsequently, $100 \mathrm{ml}$ of the buffered rumen fluid was anaerobically transferred to $160 \mathrm{ml}$ serum bottles containing either TMR or TMRF, or containing neither (control). Two g ( $1 \mathrm{~g}$ in DM basis) of the different treatment mixed feeds ( $2 \mathrm{~mm}$ screen DM particle) were then added, prior to filling with buffered rumen fluid. The buffer maintained a $\mathrm{pH}$ of 6.7 and was autoclaved prior to its addition to the rumen fluid. The filled serum bottles were then sealed with rubber stoppers and aluminum caps and incubated at $39^{\circ} \mathrm{C}$ in a shaking incubator at $90 \mathrm{rpm}$ for $0,3,6,9,12,24$ and $48 \mathrm{~h}$ with 3 replications for each of the treatments. Samples from in vitro fermentation were taken for analysis after incubation was completed.

Experiment 2 - For growth performance and blood profiles : A total of 48 Hanwoo steers were used for experimentation over $168 \mathrm{~d}$. The experimental cattle were 6 months old, with live weights of $160 \pm 10 \mathrm{~kg}$. The pens were constructed of steel frames, and each pen was $5 \mathrm{~m} \times 10 \mathrm{~m}$ in size. Each pen contained 6 cattle with 12 cattle for each treatment group, and thus 2 pens were required for each treatment. The cattle house faced toward the south to ensure proper light exposure.

Feed was supplied on the basis of the live weight of the cattle. Total mixed feed was allowed to a level of $1.7 \%$ of the total live weight of the cattle. The total feed was supplied equally to the cattle twice ( $9.00 \mathrm{am}$ and $17.00 \mathrm{pm}$ ) daily. Cattle were freely given access to fresh, clean drinking water. Trace mineral salts were made freely available for the experimental cattle, except control animals. The experimental cattle were permitted to consume diets for $2 \mathrm{wk}$ to adapt to the feed prior to beginning the experiment. Initially, the live weights of all cattle were measured. Body weights were then measured at intervals of $4 \mathrm{wk}$, and blood was collected at 8-wk intervals during the experimental period.

\section{Measurements and analytical methods}

Experiment 1 - Rumen fermentation parameters : Total gas production was measured at $3,6,9,12,24$, and $48 \mathrm{~h}$ using a press and sensor machine of EA-6 from Sun Bee Instruments, Inc., Korea. After 3, 6, 9, 12, 24, and 48 h of incubation, $\mathrm{pH}$ values were measured immediately after uncapping each bottle, and fermentation was halted by swirling the bottles on ice. The $\mathrm{pH}$ meter used to determine the $\mathrm{pH}$ value was an M530P (Schott Instruments D-55122 Mainz, Germany). The in vitro DM disappearance was measured via the two-stage method of Tilley and Terry (1963). Ammonia nitrogen concentration was measured according to the method of Chaney and Marbach (1962) using OD (extinction) at $630 \mathrm{~nm}$ by a UVspectrophotometer (Biochrom Ltd., CB40FJ, England).

VFA concentration was measured with HPLC (Agilent Technolgies 1200 series, Germany). The HPLC apparatus contained a UV detector, the column used was a Meta Carb 87H (Varian), and quantitative analysis was conducted using an Integrator. It evidenced signals of $210 \mathrm{~nm}$ and 220 $\mathrm{nm}$. The samples were centrifuged at $16,609 \times \mathrm{g}$ for $5 \mathrm{~min}$ at $4^{\circ} \mathrm{C}$ prior to use and filtered through $0.2 \mu \mathrm{m}$ Millipore filters. A standard was developed at 0.999 for VFAs prior to sample analysis.

Experiment 2 - Feed intake and weight gain calculations : Experimental cattle were weighed using a weighing machine every 4th wk of the total 24 wk experimental period. Weight gain per day was calculated by the initial body weight of the cattle deducted from the final body weight, which was divided by the experimental period (d). Feed efficiency was calculated by the weight gain per day divided by the feed intake per day of the cattle. Feed intake was also calculated by the residual feed deducted from the total supplied feed.

\section{Blood collection and analysis}

Blood was collected once at $8 \mathrm{wk}$, and after $3 \mathrm{~h}$ of feed supply. Blood samples were collected from the jugular vein. Five $\mathrm{ml}$ of blood was collected in a sterilized vacuum tube (Green Cross MS, Korea) containing $\mathrm{K}_{3}$-EDTA, and the tube was gently inverted a couple of times, kept in an ice box, and later centrifuged for $15 \mathrm{~min}$ at $890 \times \mathrm{g}$ at $4^{\circ} \mathrm{C}$ and maintained for $8 \mathrm{~h}$ in a refrigerator at $4{ }^{\circ} \mathrm{C}$ prior to analysis and separation of serum. The plasma was also transferred to a storage tube and labeled with the date and animal identification and analyzed fresh or stored at $-20^{\circ} \mathrm{C}$ until analysis. Total protein, albumin, creatinine, blood urea nitrogen and glucose concentrations were analyzed using an automatic blood analyzer (Express Plus, Ciba-Corning, CA, 
USA) according to the biuret method of Flack and Woollen (1984), the bromocresol green method of Doumas et al. (1971), the picric acid method of Husdan and Rapoport (1968), the urease method of Rocch-Ramel (1967), and the hexokinase method of Farrance (1987), respectively. Serum glutamate oxaloacetate transaminase (SGOT), serum glutamate pyruvate transaminase (SGPT), total cholesterol, high density lipo protein (HDL), low density lipo protein (LDL) and triglyceride concentrations of the blood samples were analyzed by Green Cross MS in Korea.

\section{Statistical analysis}

Results obtained from the experiment were analyzed by one-way ANOVA for variance using the GLM (General Linear Model) procedure of the SAS (2004) 9.1 Soft Ware
Package and authorized synonymy between averages were determined by Duncan's multiple range test method. Significant differences were accepted if $\mathrm{p}<0.05$.

\section{RESULTS}

\section{Rumen fermentation characteristics (Experiment 1)}

Total gas production and $\mathrm{pH}$ value : In vitro gas production at different stages, concentrations of $\mathrm{NH}_{3}-\mathrm{N}$ and $\mathrm{pH}$ value in rumen fluid were employed to monitor the ruminal fermentation pattern (Table 2). Total gas production increased gradually from 3 to $48 \mathrm{~h}$ in all of the treatment groups. Gas production increased with incubation and fermentation period. Total gas production differed prominently from 12 to $24 \mathrm{~h}$ of incubation among the

Table 2. Total gas production, $\mathrm{pH}$ values, ammonia-nitrogen concentration and disappearance rate of DM in in vitro ruminal fermentation of experimental diets at different stages for Exp. 1

\begin{tabular}{|c|c|c|c|c|c|}
\hline \multirow{2}{*}{ Incubation time (h) } & \multicolumn{4}{|c|}{ Treatments } & \multirow{2}{*}{$\begin{array}{c}\text { Level of } \\
\text { significance }\end{array}$} \\
\hline & $\mathrm{T} 1^{1}$ & $\mathrm{~T}^{2}{ }^{2}$ & $\mathrm{~T}^{3}$ & SEM & \\
\hline \multicolumn{6}{|c|}{ Gas production (ml/g DM) } \\
\hline 3 & $27.00^{\mathrm{a}}$ & $21.34^{\mathrm{c}}$ & $24.17^{\mathrm{b}}$ & 0.89 & $*$ \\
\hline 6 & 36.00 & 33.84 & 33.84 & 1.50 & NS \\
\hline 9 & 38.00 & 39.50 & 40.17 & 1.72 & NS \\
\hline 12 & $40.50^{\mathrm{b}}$ & $47.00^{\mathrm{ab}}$ & $51.17^{\mathrm{a}}$ & 3.05 & * \\
\hline 24 & $53.84^{\mathrm{b}}$ & $50.17^{\mathrm{b}}$ & $61.50^{\mathrm{a}}$ & 2.82 & * \\
\hline 48 & 56.00 & 60.00 & 64.67 & 6.32 & NS \\
\hline \multicolumn{6}{|l|}{$\mathrm{pH}$ values } \\
\hline 3 & $5.59^{\mathrm{b}}$ & $5.78^{\mathrm{a}}$ & $5.83^{\mathrm{a}}$ & 0.03 & * \\
\hline 6 & $5.23^{\mathrm{b}}$ & $5.43^{\mathrm{a}}$ & $5.45^{\mathrm{a}}$ & 0.04 & $*$ \\
\hline 9 & 5.12 & 5.33 & 5.29 & 0.06 & NS \\
\hline 12 & 5.15 & 5.16 & 5.09 & 0.02 & NS \\
\hline 24 & 4.98 & 4.97 & 4.95 & 0.02 & NS \\
\hline 48 & 4.92 & 4.86 & 4.82 & 0.03 & NS \\
\hline \multicolumn{6}{|c|}{$\mathrm{NH}_{3}-\mathrm{N}$ concentration $(\mathrm{mg} / \mathrm{L})$} \\
\hline 3 & 227.00 & 226.00 & 243.33 & 28.56 & NS \\
\hline 6 & 243.00 & 231.33 & 246.33 & 16.37 & NS \\
\hline 9 & 245.67 & 239.44 & 262.67 & 32.94 & NS \\
\hline 12 & 261.67 & 254.00 & 330.67 & 43.83 & NS \\
\hline 24 & 291.44 & 261.44 & 344.22 & 25.69 & NS \\
\hline 48 & 356.44 & 328.67 & 345.78 & 29.38 & NS \\
\hline \multicolumn{6}{|c|}{ Disappearance rate of DM (g/kg) } \\
\hline 3 & $644.80^{\mathrm{a}}$ & $628.00^{\mathrm{a}}$ & $535.80^{b}$ & 0.02 & $*$ \\
\hline 6 & $641.80^{\mathrm{a}}$ & $637.20^{\mathrm{a}}$ & $547.90^{\mathrm{b}}$ & 0.02 & $*$ \\
\hline 9 & $661.20^{\mathrm{ab}}$ & $679.90^{\mathrm{a}}$ & $586.60^{b}$ & 0.03 & $*$ \\
\hline 12 & $677.60^{\mathrm{ab}}$ & $699.80^{\mathrm{a}}$ & $615.00^{\mathrm{b}}$ & 0.02 & $*$ \\
\hline 24 & 713.50 & 729.90 & 667.30 & 0.02 & NS \\
\hline 48 & 718.10 & 744.30 & 703.60 & 0.01 & NS \\
\hline
\end{tabular}

Values are given as means $(\mathrm{n}=3)$. Different letters $\left({ }^{\mathrm{a}, \mathrm{b}, \mathrm{c}}\right)$ within each row indicate significant differences within the values $(\mathrm{p}<0.05)$.

${ }^{1}$ Tall fescue, $184 \mathrm{~g} / \mathrm{kg}$ fermented feed, mammoth wild rye forage, whole barley forage etc.

${ }^{2}$ Rice straw, $177 \mathrm{~g} / \mathrm{kg}$ fermented feed, whole barley forage etc. ${ }^{3}$ Rice straw, probiotics, whole barley forage etc.

${ }^{4}$ The total gas was produced from $1 \mathrm{~g}$ (DM basis) of feed substrates, which were used in each of the serum bottles during in vitro fermentation. 
treatment groups. At the beginning of the experiment the $\mathrm{pH}$ value was 6.01 , and by the end of the experiment it was changed to $4.86 \pm 0.06$. The $\mathrm{pH}$ value at $6 \mathrm{~h}$ of incubation was higher in the $\mathrm{T} 2$ and $\mathrm{T} 3$ treatment groups than in the others (Table 2). $\mathrm{pH}$ values measured at 9 to $48 \mathrm{~h}$ did not differ significantly ( $\mathrm{p}>0.05)$.

$\mathrm{NH}_{3}-\mathrm{N}$ concentration and DM disappearance : Though $\mathrm{NH}_{3}-\mathrm{N}$ concentration gradually increased with the advancement of incubation, but did not differ between the treatments $(\mathrm{p}>0.05)$ (Table 2). DM disappearance was highest in T2 (69.98) followed by T1 (67.76) and T3 (61.50) at $12 \mathrm{~h}$ of incubation $(\mathrm{p}<0.05)$. DM disappearance rate gradually increased with advancing fermentation time in all of the groups, but the disappearance rate in T1 and T2 was higher than the T3 and achieved significance $(\mathrm{p}<0.05)$ from 3 to 12 h, but was insignificant $(\mathrm{p}>0.05)$ at 24 and 48 h (Table 2).

Volatile fatty acid, lactate and $\mathrm{A} / \mathrm{P}$ ratio : The VFAs and lactate concentrations of the different treatments are provided in Table 3. All types of VFA increased gradually from 0 to $48 \mathrm{~h}$ and lactic acid was reduced after $9 \mathrm{~h}$ of incubation. None of the specific VFAs were affected by the treatments except for acetate and non-VFA lactate which were produced comparatively more in $\mathrm{T} 2$ than $\mathrm{T} 1$ and $\mathrm{T} 3$ at 24 and $48 \mathrm{~h}$ of incubation (Table 3). A/P gradually decreased with advancing rumen fermentation period and differed significantly $(\mathrm{p}<0.05)$ at 3,12 and $24 \mathrm{~h}$ of incubation (Table 3).

\section{Growth performance and blood profiles (Experiment 2)}

Feed intake and weight gain : The initial and final body weights of the experimental Hanwoo steers were on an average 159.6 and $301.3 \mathrm{~kg}$, respectively. At the end of the experiment, the T1 (308.0 kg) weights were the highest and the control weights $(284.0 \mathrm{~kg})$ were lowest $(\mathrm{p}<0.05)$. The highest live weight gain (LWG) was detected in the T3 group and the lowest was detected in the controls (Table 4). However, the LWG of the T1, T2, and T3 groups were quite similar, and daily live weight gain values were the same in all treatment groups except the controls, which evidenced the lowest weights. TMR and TMRF feed related treatments yielded higher body weight gains than were seen in the control group $(\mathrm{p}<0.05)$. Feed intake was higher in the control group than in the other treatment groups (Table 4). Feed efficiency was identical (0.16) in the T1, T2, and T3 groups, but the control group evidenced the lowest values (0.12).

Changes of blood profiles : Changes of blood profile according to different treatment groups are shown in Table 5. Total blood protein content was unchanged from 56 to $168 \mathrm{~d}(\mathrm{p}<0.05)$ in $\mathrm{T} 1$ and $\mathrm{T} 2$, but was slightly increased in the T3 group and decreased in the control group. The albumin concentrations were increased prior to the final test in all treatment groups (Table 5). Serum Glutamate Oxaloacetate Transaminase (SGOT) concentrations were unchanged in the $\mathrm{T} 1$ and $\mathrm{T} 2$ groups from prior to final, but increased only slightly in the T3 and control groups. Serum Glutamate Pyruvate Transaminase (SGPT) concentration levels were reduced in all treatment groups from 56 to 168 $\mathrm{d}(\mathrm{p}<0.05)$. Creatinine concentrations decreased in the $\mathrm{T} 1$ and T2 groups from before the test to the final test, but increased in the T3 and control groups (Table 5). Blood urea nitrogen (BUN) levels were reduced for all of the treatment groups, but $\mathrm{T} 1$ and $\mathrm{T} 2$ were reduced more and $\mathrm{T} 3$ and control decreased less profoundly from $56 \mathrm{~d}$ to $168 \mathrm{~d}$. Total cholesterol levels increased from initial to the final test for all of the treatment groups. However, these levels increased more in the TMR and TMRF feed groups relative to the controls (Table 5). High density lipo protein (HDL) increased for all of the treatments including the controls ( $>0.05$ ). Low density lipo protein (LDL) also increased for all of the treatments, including the controls. Triglyceride concentrations reduced from the 56 to the 168-d blood test in all the treatment groups, but the controls were nearly identical, and did not change. Glucose levels increased from 56 to $112 \mathrm{~d}(\mathrm{p}<0.05)$, and then declined at $168 \mathrm{~d}(\mathrm{p}>0.05)$ in the case of all of the treatment groups, including the controls.

\section{DISCUSSIONS}

\section{Experiment 1 for in vitro fermentation characteristics}

The results of the experiment confirmed that fermental gas production increased with the advancing incubation period. Mao et al. (2007) noted that the total gas production would increase with advancing rumen fermentation period of the substrate. This consistency illustrates the similarity between present and previous research results. The $\mathrm{pH}$ values of the present experiment did not differ according to the effects of different TMR and TMRF, but all gradually decreased with the time period. It is assumed that the decrease in $\mathrm{pH}$ was due to the increased level of VFA and lactate.

$\mathrm{NH}_{3}-\mathrm{N}$ is regarded as the most important nitrogen source for microbial protein synthesis in the rumen (Bryant, 1974) and the level in the rumen is generally high when the feeds are more digestible. The differences in $\mathrm{NH}_{3}-\mathrm{N}$ concentrations among treatments may be directly related to urea and protein degradability in the TMRs. High ammonium nitrogen levels indicates that the soluble fraction of protein is also high. Erdman et al. (1986) reported previously that ammonia nitrogen contents are increased with the increased digestion period in the ruminant stomach. Slyter et al. (1979) and Li et al. (2003b) reported that cattle on TMR related feed content evidence higher ruminal $\mathrm{NH}_{3}-\mathrm{N}$ levels with the fermentation periods; 
Table 3. Changes of VFA, lactate concentrations and A/P in in vitro fermentation of experimental diets at different incubation periods for Exp. 1

\begin{tabular}{|c|c|c|c|c|c|}
\hline \multirow{2}{*}{ Fermentation period (h) } & \multicolumn{4}{|c|}{ Treatments } & \multirow{2}{*}{ Level of significance } \\
\hline & $\mathrm{T}^{1}{ }^{1}$ & $\mathrm{~T} 2^{2}$ & $\mathrm{~T}^{3}$ & SEM & \\
\hline \multicolumn{6}{|l|}{ Acetic acid (mM/L) } \\
\hline 0 & $21.17^{\mathrm{a}}$ & $19.08^{\mathrm{a}}$ & $14.20^{\mathrm{b}}$ & 1.35 & * \\
\hline 3 & 20.97 & 29.44 & 23.83 & 4.24 & NS \\
\hline 6 & $33.60^{\mathrm{a}}$ & $22.43^{\mathrm{b}}$ & $22.42^{\mathrm{b}}$ & 2.24 & $*$ \\
\hline 9 & $22.84^{\mathrm{b}}$ & $22.73^{\mathrm{b}}$ & $30.48^{\mathrm{a}}$ & 1.91 & $*$ \\
\hline 12 & 30.72 & 36.45 & 31.95 & 2.49 & NS \\
\hline 24 & $44.23^{\mathrm{b}}$ & $54.65^{\mathrm{a}}$ & $46.13^{\mathrm{ab}}$ & 2.99 & $*$ \\
\hline 48 & 53.78 & 60.15 & 52.01 & 7.28 & NS \\
\hline \multicolumn{6}{|l|}{ Propionic acid } \\
\hline 0 & 5.02 & 5.01 & 2.86 & 1.33 & NS \\
\hline 3 & 6.15 & 6.09 & 6.53 & 0.78 & NS \\
\hline 6 & 11.25 & 9.25 & 9.96 & 1.24 & NS \\
\hline 9 & 10.32 & 11.60 & 11.71 & 1.81 & NS \\
\hline 12 & 17.93 & 27.04 & 25.30 & 2.79 & NS \\
\hline 24 & 38.70 & 43.60 & 36.03 & 2.79 & NS \\
\hline 48 & 46.90 & 49.91 & 38.93 & 4.75 & NS \\
\hline \multicolumn{6}{|l|}{ Butyric acid } \\
\hline 0 & 3.49 & 2.50 & 2.78 & 0.63 & NS \\
\hline 3 & 4.57 & 3.20 & 4.32 & 0.87 & NS \\
\hline 6 & 5.62 & 4.12 & 5.44 & 0.63 & NS \\
\hline 9 & 3.67 & 3.35 & 5.04 & 0.64 & NS \\
\hline 12 & 5.41 & 4.71 & 5.52 & 0.74 & NS \\
\hline 24 & 9.98 & 5.82 & 6.23 & 1.58 & NS \\
\hline 48 & 9.00 & 7.47 & 6.16 & 1.15 & NS \\
\hline \multicolumn{6}{|l|}{ Total VFA } \\
\hline 0 & $29.68^{\mathrm{a}}$ & $26.59^{\mathrm{ab}}$ & $19.84^{\mathrm{b}}$ & 2.39 & $*$ \\
\hline 3 & 31.69 & 38.73 & 34.69 & 4.83 & NS \\
\hline 6 & $50.48^{\mathrm{a}}$ & $35.80^{\mathrm{b}}$ & $37.81^{\mathrm{b}}$ & 2.97 & $*$ \\
\hline 9 & 36.83 & 37.68 & 47.23 & 3.30 & NS \\
\hline 12 & 54.07 & 68.20 & 62.77 & 4.91 & NS \\
\hline 24 & 92.91 & 104.07 & 88.40 & 6.41 & NS \\
\hline 48 & 109.69 & 117.53 & 97.10 & 11.19 & NS \\
\hline \multicolumn{6}{|l|}{ Lactic acid } \\
\hline 0 & 6.28 & 5.18 & 4.61 & 0.62 & NS \\
\hline 3 & $19.76^{\mathrm{a}}$ & $12.39^{\mathrm{b}}$ & $11.33^{\mathrm{b}}$ & 1.38 & * \\
\hline 6 & $24.34^{\mathrm{a}}$ & $17.28^{\mathrm{b}}$ & $15.92^{\mathrm{b}}$ & 1.36 & * \\
\hline 9 & $26.06^{\mathrm{ab}}$ & $19.32^{\mathrm{b}}$ & $30.29^{\mathrm{a}}$ & 3.03 & * \\
\hline 12 & $21.06^{\mathrm{a}}$ & $4.78^{\mathrm{b}}$ & $11.62^{\mathrm{b}}$ & 2.28 & * \\
\hline 24 & 4.27 & 7.60 & 6.86 & 1.17 & NS \\
\hline 48 & 4.42 & 6.78 & 5.15 & 1.32 & NS \\
\hline \multicolumn{6}{|l|}{$\mathrm{A} / \mathrm{P}$ ratio } \\
\hline 3 & 3.40 & 5.47 & 3.81 & 0.74 & NS \\
\hline 6 & 3.83 & 2.44 & 2.45 & 0.60 & NS \\
\hline 9 & 2.35 & 2.16 & 3.08 & 0.36 & NS \\
\hline 12 & $2.23^{\mathrm{a}}$ & $1.36^{\mathrm{b}}$ & $1.32^{\mathrm{b}}$ & 0.23 & * \\
\hline 24 & 1.15 & 1.27 & 1.34 & 0.09 & NS \\
\hline 48 & 1.15 & 1.29 & 1.29 & 0.12 & NS \\
\hline
\end{tabular}

Values are given as means $(\mathrm{n}=3){ }^{\mathrm{a}, \mathrm{b}}$ Different letters within each row indicate significant differences within the values $(\mathrm{p}<0.05)$.

${ }^{1}$ Tall fescue, $184 \mathrm{~g} / \mathrm{kg}$ fermented feed, mammoth wild rye forage, whole barley forage etc.

${ }^{2}$ Rice straw, $177 \mathrm{~g} / \mathrm{kg}$ fermented feed, whole barley forage etc. ${ }^{3}$ Rice straw, probiotics, whole barley forage etc. 
Table 4. Growth performance and feed efficiency of growing Hanwoo steers by feeding different diets for Exp. 2

\begin{tabular}{|c|c|c|c|c|c|c|c|}
\hline \multirow{2}{*}{ Periods/item } & & \multicolumn{5}{|c|}{ Treatments } & \multirow{3}{*}{$\begin{array}{c}\text { Level of } \\
\text { significance }\end{array}$} \\
\hline & & Con $^{1}$ & $\mathrm{~T} 1^{2}$ & $\mathrm{~T}^{3}$ & $\mathrm{~T}^{4}$ & SEM & \\
\hline Days & Unit & & & & & & \\
\hline $\mathrm{IBW}^{5}$ & \multirow{10}{*}{$\begin{array}{l}\text { Weight } \\
\text { (kg) }\end{array}$} & 160.33 & 160.42 & 158.92 & 158.58 & 4.47 & NS \\
\hline 28 & & 187.92 & 190.83 & 182.75 & 184.67 & 5.48 & NS \\
\hline 56 & & 201.17 & 206.83 & 191.67 & 199.00 & 5.57 & NS \\
\hline 84 & & 210.08 & 221.50 & 202.83 & 212.92 & 6.08 & NS \\
\hline 112 & & 237.00 & 252.92 & 247.33 & 256.08 & 6.30 & NS \\
\hline 140 & & 258.83 & 275.42 & 267.58 & 278.42 & 6.92 & NS \\
\hline FBW $^{6}$ & & 284.00 & 308.00 & 306.08 & 307.00 & 7.83 & NS \\
\hline TLWG $^{7}$ & & $123.67^{b}$ & $147.58^{\mathrm{a}}$ & $147.17^{\mathrm{a}}$ & $148.42^{\mathrm{a}}$ & 5.69 & * \\
\hline $\mathrm{DLWG}^{8}$ & & $0.74^{\mathrm{b}}$ & $0.88^{\mathrm{a}}$ & $0.88^{\mathrm{a}}$ & $0.88^{\mathrm{a}}$ & 0.04 & * \\
\hline $\mathrm{DFI}^{9}$ & & 6.43 & 5.63 & 5.63 & 5.63 & 0.35 & NS \\
\hline $\mathrm{FE}^{10}$ & Ratio & $0.12^{\mathrm{b}}$ & $0.16^{\mathrm{a}}$ & $0.16^{\mathrm{a}}$ & $0.16^{\mathrm{a}}$ & 0.01 & * \\
\hline
\end{tabular}

Values are given as means $\left(\mathrm{n}=3\right.$ ). ${ }^{\mathrm{a}, \mathrm{b}}$ Different letters within each row indicate significant differences within the values ( $<<0.05$ ).

${ }^{1}$ As usual mixed diet. ${ }^{2}$ Tall fescue, $184 \mathrm{~g} / \mathrm{kg}$ fermented feed, mammoth wild rye forage, whole barley forage etc.

${ }^{3}$ Rice straw, $177 \mathrm{~g} / \mathrm{kg}$ fermented feed, whole barley forage etc. ${ }^{4}$ Rice straw, probiotics, whole barley forage etc. ${ }^{5}$ Initial body weight (starting).

${ }^{6}$ Final body weight (168 d). ${ }^{7}$ Total live weight gain. ${ }^{8}$ Daily live weight gain. ${ }^{9}$ Daily feed intake. ${ }^{10}$ Feed efficiency $=$ DLWG/DFI.

the results of the present study agrees with the findings of previous studies. TMR increases the concentration of soluble sugars and lactic acid from feed; thus, the higher ruminal degradability of DM and fermented feed reduced $\mathrm{pH}$ and sugar concentrations, enhancing lactic acid production, which facilitates DM disappearance (Hristov and McAllister, 2002). DM disappearance is frequently marginal and depends heavily on the microbial fermentation of feed (Patterson et al., 1997; Mandebvu et al., 1999). The findings of the present experiment also revealed the same relationship between fermentation period and DM disappearance, which is consistent with the findings of previous research.

VFA is the first source of energy for ruminant animals, and is influenced by the feed quality, quantity, allowance method etc. (McCarthy et al., 1989; Casper et al., 1990). Acetate and butyrate may be used for energy supply to animals, but propionate can be employed as a primary source of glucose. However, all VFAs constitute an excellent source of energy for fattening cattle. In the present study, VFA increased gradually with increased incubation periods. VFA production has been reported to depend largely on the level of hay in the ration and the quantity of hay consumed (Sasaki et al., 2001). Although the present experiment did not directly use hay, it did use the TMRF and TMR, which induced a comparatively higher level of VFA production with advancing incubation period. However, these alterations were less profound, which is consistent with the findings of $\mathrm{Li}$ et al. (2003b). Overton et al. (1995) previously reported that ruminal VFA production depends on feed composition, feed intake and the feeding system used. The TMR and TMR with fermented feed partially affect VFA production which is partially consistent with the aforementioned reports. There is also some evidence to suggest that the rate and extent of carbohydrate degradation are affected by the condition of rumen fermentation and the rate and extent of VFA production (Cheng et al., 1991). Keady and Mayne (2001) also demonstrated that VFA concentrations were similar when the animals consumed diets containing similar carbohydrate compositions. In this study, different sources of fiber in TMR and TMRF were employed; thus, VFA concentrations and VFA profiles also differed in some specific incubation periods. Also, the different sources of fiber in TMR and TMRF caused the concentration of acetate to differ at $24 \mathrm{~h}$ of incubation. Lactate concentrations differed at 3, 6, 9 and $12 \mathrm{~h}$ of incubation which gradually decreased with the time periods. McGilliard et al. (1983) and Nock et al. (1985) reported that the TMR and TMRF systems helped to maintain the rumen $\mathrm{A} / \mathrm{P}$ ratio, because TMR and TMRF could provide a more balanced ration with a uniform rate of roughage and concentrate and increased DM intake. Li et al. (2003a) reported previously that TMR feeding resulted in lower $\mathrm{A} / \mathrm{P}$ ratios, which is good for ruminants. The present findings showed better $\mathrm{A} / \mathrm{P}$ in the TMRF group (T1 and T2) than in the TMR (T3) group at $12 \mathrm{~h}$ of fermentation, which is consistent with the above previous research findings showing a beneficial effect on ruminants.

\section{Experiment 2 for growth performances and blood profile characteristics}

Growth performances : Lin et al. $(2001 ; 2004)$ reported previously that body weight gain and feed conversion rates 
Table 5. Blood characteristics of growing Hanwoo steers on different diets for Exp. 2

\begin{tabular}{|c|c|c|c|c|c|c|c|}
\hline \multirow{2}{*}{ Items } & \multirow{2}{*}{ Unit } & \multicolumn{5}{|c|}{ Treatments } & \multirow{2}{*}{$\begin{array}{c}\text { Level of } \\
\text { significance }\end{array}$} \\
\hline & & Con $^{1}$ & $\mathrm{~T} 1^{2}$ & $\mathrm{~T} 2^{3}$ & $\mathrm{~T}^{4}{ }^{4}$ & SEM & \\
\hline \multicolumn{8}{|l|}{ After $56 \mathrm{~d}$} \\
\hline Total protein & $\mathrm{g} / \mathrm{dl}^{5}$ & $6.65^{\mathrm{a}}$ & $6.11^{\mathrm{b}}$ & $6.48^{\mathrm{a}}$ & $6.13^{\mathrm{b}}$ & 0.12 & * \\
\hline Albumin & $\mathrm{g} / \mathrm{dl}$ & 3.49 & 3.40 & 3.45 & 3.48 & 0.09 & NS \\
\hline $\mathrm{SGOT}^{6}$ & $\mathrm{IU} / \mathrm{L}^{8}$ & $66.17^{\mathrm{b}}$ & $71.50^{\mathrm{ab}}$ & $66.42^{\mathrm{b}}$ & $78.00^{\mathrm{a}}$ & 3.61 & $*$ \\
\hline $\mathrm{SGPT}^{7}$ & $\mathrm{IU} / \mathrm{L}$ & 25.75 & 27.67 & 27.00 & 26.67 & 1.45 & NS \\
\hline Creatinine & $\mathrm{mg} / \mathrm{dl}$ & $1.53^{\mathrm{a}}$ & $1.36^{\mathrm{b}}$ & $1.32^{\mathrm{b}}$ & $1.20^{\mathrm{b}}$ & 0.06 & * \\
\hline BUN $^{9}$ & $\mathrm{mg} / \mathrm{dl}$ & $13.57^{\mathrm{a}}$ & $11.89^{\mathrm{ab}}$ & $9.69^{c}$ & $10.82^{\mathrm{bc}}$ & 0.67 & * \\
\hline Total cholesterol & $\mathrm{mg} / \mathrm{dl}$ & $113.92^{\mathrm{ab}}$ & $120.25^{\mathrm{a}}$ & $104.00^{\mathrm{ab}}$ & $101.17^{\mathrm{b}}$ & 5.69 & * \\
\hline HDL $^{10}$ cholesterol & $\mathrm{mg} / \mathrm{dl}$ & 55.50 & 60.25 & 53.58 & 53.75 & 2.41 & NS \\
\hline LDL $^{11}$ cholesterol & $\mathrm{mg} / \mathrm{dl}^{12}$ & 11.83 & 12.67 & 10.83 & 11.58 & 0.72 & NS \\
\hline Triglyceride & $\mathrm{mg} / \mathrm{dl}$ & 27.83 & 28.08 & 31.17 & 26.08 & 1.87 & NS \\
\hline Glucose & $\mathrm{mg} / \mathrm{dl}$ & $89.75^{a b}$ & $95.08^{\mathrm{a}}$ & $88.50^{\mathrm{b}}$ & $92.75^{\mathrm{ab}}$ & 2.07 & $*$ \\
\hline \multicolumn{8}{|l|}{ After $112 \mathrm{~d}$} \\
\hline Total protein & $\mathrm{g} / \mathrm{dl}$ & 6.22 & 5.92 & 6.20 & 5.97 & 0.14 & NS \\
\hline Albumin & $\mathrm{g} / \mathrm{dl}$ & $3.46^{\mathrm{b}}$ & $3.61^{\mathrm{a}}$ & $3.63^{\mathrm{a}}$ & $3.63^{\mathrm{a}}$ & 0.05 & * \\
\hline SGOT & $\mathrm{IU} / \mathrm{L}$ & 63.17 & 73.08 & 76.08 & 77.33 & 4.52 & NS \\
\hline SGPT & $\mathrm{IU} / \mathrm{L}$ & $22.00^{\mathrm{b}}$ & $25.75^{\mathrm{a}}$ & $23.75^{\mathrm{ab}}$ & $22.25^{\mathrm{b}}$ & 1.04 & $*$ \\
\hline Creatinine & $\mathrm{mg} / \mathrm{dl}$ & 1.28 & 1.34 & 1.33 & 1.27 & 0.05 & NS \\
\hline BUN & $\mathrm{mg} / \mathrm{dl}$ & $10.22^{\mathrm{ab}}$ & $11.75^{\mathrm{a}}$ & $10.17^{\mathrm{ab}}$ & $9.03^{b}$ & 0.56 & $*$ \\
\hline Total cholesterol & $\mathrm{mg} / \mathrm{dl}$ & $129.67^{\mathrm{a}}$ & $108.33^{b}$ & $120.58^{\mathrm{ab}}$ & $111.00^{\mathrm{b}}$ & 5.13 & * \\
\hline HDL cholesterol & $\mathrm{mg} / \mathrm{dl}$ & $66.25^{\mathrm{a}}$ & $55.17^{\mathrm{b}}$ & $65.00^{\mathrm{a}}$ & $59.58^{\mathrm{ab}}$ & 2.32 & * \\
\hline LDL cholesterol & $\mathrm{mg} / \mathrm{dl}$ & 12.58 & 11.42 & 11.92 & 10.83 & 0.58 & NS \\
\hline Triglyceride & $\mathrm{mg} / \mathrm{dl}$ & $28.42^{\mathrm{a}}$ & $27.92^{\mathrm{a}}$ & $20.17^{\mathrm{b}}$ & $18.83^{\mathrm{b}}$ & 1.81 & * \\
\hline Glucose & $\mathrm{mg} / \mathrm{dl}$ & $97.25^{\mathrm{b}}$ & $101.92^{\mathrm{ab}}$ & $100.67^{\mathrm{ab}}$ & $105.67^{\mathrm{a}}$ & 1.93 & $*$ \\
\hline \multicolumn{8}{|l|}{ After $168 \mathrm{~d}$} \\
\hline Total protein & $\mathrm{g} / \mathrm{dl}$ & $6.28^{\mathrm{ab}}$ & $6.11^{\mathrm{b}}$ & $6.47^{\mathrm{a}}$ & $6.31^{\mathrm{ab}}$ & 0.09 & $*$ \\
\hline Albumin & $\mathrm{g} / \mathrm{dl}$ & $3.65^{\mathrm{c}}$ & $3.72^{\mathrm{bc}}$ & $3.89^{\mathrm{a}}$ & $3.84^{\mathrm{ab}}$ & 0.05 & * \\
\hline SGOT & $\mathrm{IU} / \mathrm{L}$ & $61.75^{\mathrm{b}}$ & $71.33^{\mathrm{a}}$ & $66.00^{\mathrm{ab}}$ & $69.67^{\mathrm{a}}$ & 2.44 & * \\
\hline SGPT & $\mathrm{IU} / \mathrm{L}$ & $20.75^{b}$ & $26.50^{\mathrm{a}}$ & $23.33^{b}$ & $22.08^{\mathrm{b}}$ & 0.98 & $*$ \\
\hline Creatinine & $\mathrm{mg} / \mathrm{dl}$ & 1.28 & 1.33 & 1.27 & 1.23 & 0.04 & NS \\
\hline BUN & $\mathrm{mg} / \mathrm{dl}$ & $13.30^{\mathrm{a}}$ & $9.82^{\mathrm{b}}$ & $10.72^{\mathrm{b}}$ & $10.38^{\mathrm{b}}$ & 0.52 & * \\
\hline Total cholesterol & $\mathrm{mg} / \mathrm{dl}$ & 121.93 & 135.17 & 145.42 & 142.25 & 8.33 & NS \\
\hline HDL cholesterol & $\mathrm{mg} / \mathrm{dl}$ & 59.25 & 62.50 & 61.08 & 60.58 & 2.49 & NS \\
\hline LDL cholesterol & $\mathrm{mg} / \mathrm{dl}$ & 16.83 & 17.92 & 18.92 & 19.50 & 1.36 & NS \\
\hline Triglyceride & $\mathrm{mg} / \mathrm{dl}$ & 27.67 & 26.25 & 23.83 & 23.67 & 1.56 & NS \\
\hline Glucose & $\mathrm{mg} / \mathrm{dl}$ & 86.50 & 89.75 & 91.17 & 91.50 & 2.13 & NS \\
\hline
\end{tabular}

Values are given as means $(\mathrm{n}=3)$. Different letters $\left({ }^{\mathrm{a}, \mathrm{b}, \mathrm{c}}\right)$ within each row indicate significant differences within the values $(\mathrm{p}<0.05)$.

${ }^{1}$ As usual mixed diet. ${ }^{2}$ Tall fescue, $184 \mathrm{~g} / \mathrm{kg}$ fermented feed, mammoth wild rye forage, whole barley forage etc.

${ }^{3}$ Rice straw, $177 \mathrm{~g} / \mathrm{kg}$ fermented feed, whole barley forage etc. ${ }^{4}$ Rice straw, probiotics, whole barley forage etc.

${ }^{5}$ Gram per deci liter (g/dl). ${ }^{6}$ Serum glutamate oxaloacetate transaminase (SGOT).

${ }^{7}$ Serum glutamate pyruvate transaminase (SGPT). ${ }^{8}$ International unit per liter (IU/L). ${ }^{9}$ Blood urea nitrogen (BUN).

${ }^{10}$ High density lipoprotein (HDL). ${ }^{11}$ Low density lipoprotein (LDL). ${ }^{12} \mathrm{mg}$ per deci liter (mg/dl).

of Hanwoo steers at the end of the fattening period were improved by the consumption of fermented feedstuffs. The feed efficiency results from the present experiment were consistent with these findings, though the final body weight did not differ among treatment and control. These results demonstrate that TMR and TMRF feed in the ration 
improve nutrient utilization in ruminal fermentation and is consistent with the opinions of McGilliard et al. (1983) and Nock et al. (1985). For this reason, the control group failed to achieve growth relative to that seen with TMRF and TMR. Apparently the higher moisture content and lower nutritive value of the feed could not be properly utilized in the stomach (Ministry of Agriculture and Forestry, Republic of Korea, 2002). However, TMR or TMRF can modify moisture contents and nutritive values, which may improve feed efficiency as well as body weight gain.

Blood metabolites : Total protein and albumin concentrations are correlated. It is shown in this experiment that higher total protein or blood albumin content is associated with greater body weight gains. It has been previously reported that blood albumin concentration was decreased with increasing synthesis of muscle proteins (Galbraith et al., 1978), although this is inconsistent with the findings of the present study. Rather, our finding show a relationship between increased levels of blood total protein or albumin and increased body weight at $168 \mathrm{~d}$ and is consistent with the findings reported previously by Enright et al. (1990). TMRF and TMR groups achieved a better performance than the control group, consistent with the above statements. Low levels of SGOT and SGPT are favorable for healthy cattle at $168 \mathrm{~d}$, and similar results were reflected in our present experimental findings with TMRF. The correlation between serum glucose and creatinine up to $112 \mathrm{~d}$ was also greater in the fermented feed treatment group relative to the controls. This is probably related to the reduced Krebs cycle activity associated with fermented feed. Our findings regarding creatinine are consistent with the findings reported by Erkki et al. (1998). A marked correlation between BUN and $\mathrm{NH}_{3}-\mathrm{N}$ concentrations in the rumen was previously detected (Church, 1972). Thus, animals fed with TMR and TMRF also evidenced higher BUN levels than the controls at $168 \mathrm{~d}$. Protein degradation occurs more rapidly than synthesis or imbalances of fermentable energy and available nitrogen, and thus ammonia will accumulate in the rumen fluid and be absorbed into the blood where it is transported to the liver and converted to urea. Since BUN is generated during the excretion of ammonia in urine via the urea cycle, the lower correlation between serum BUN and protein in steers fed on fermented feed could result principally from the increase in BUN levels and the reduction in protein synthesis, and vice versa (Charles, 1999). Our experiment showed this phenomenon in reverse; namely, a reduction in BUN and an increase in protein levels. However, the findings regarding BUN levels in the present study were consistent with the findings of Ellenberger et al. (1989). Lin et al. (2001, 2004) noted that blood cholesterol concentrations are generally proportional to the increment of body weight. The findings of this experiment did not differ with regard to blood cholesterol concentrations among the control and treatment groups. From a different experimental viewpoint, it was established that HDL is better than LDL for the animal body, but the concentrations of both depend on the levels of weight gain. Body fat is correlated with HDL and LDL concentrations; if body weight or fat increase, ultimately HDL and LDL will also increase. The findings of this study revealed similar HDL levels in TMR and TMRF, which were favorable for animals and similar to the views described above. Lin et al. (2001, 2004) reported that the provision of alcoholfermented feed to ruminants increased the propionate, triglyceride, cholesterol and glucose concentrations in the blood with increasing weight gain. However, it remains unclear whether or not the alcohol-fermented feed directly increases metabolic efficiency in the stomach; this was inconsistent with the present results, even though this study used TMRF and TMR rather than alcohol-fermented feed. The present results demonstrate that TMRF and TMR can be applied to modulate the nutritional metabolism and growth characteristics of Korean native Hanwoo steers.

According to the findings of fermentation characteristics, a fermented diet produced comparatively better results while tall fescue and rice straw in the diet showed a similar performance to that of TMR during the $48 \mathrm{~h}$ incubation period. Growth performances were confirmed better in the fermented and TMR groups and similar both in tall fescue and rice straw than in the control diet group. Blood profile characteristics were nearly similar in fermented, tall fescue and rice straw TMR and control groups by $168 \mathrm{~d}$ of the trial; indicating that the tested feeds were as suitable for healthy cattle as the control. Thus, our findings show that the provision of TMRF with domestic straw and whole barley-based feed is favorable and had no detrimental effect on nutritional aspects in Hanwoo cattle. Futher investigation is required to advance methods of improving cattle productivity through the use of TMRF.

\section{ACKNOWLEDGEMENTS}

This work was carried out with the support of "Cooperative Research Program for Agriculture Science \& Technology Development (Project No. PJ0063952010)” Rural Development Administration and Korea Institute of planning \& Evaluation for Technology in Food, Agriculture \& Fisheries, Republic of Korea.

\section{REFERENCES}

AOAC. 1995. Official methods of analysis. 16th edn. Association of Official Analytical Chemists, Virginia, USA.

Bryant, M. P. 1974. Nutritional features and ecology of predominant anaerobic bacteria of the intestinal tract. Am. J. Clin. Nutr. 27:1313-1319. 
Casper, D. P., D. J. Schingoethe and W. A. Eisenbeisz. 1990. Response of early lactation dairy cows fed diets varying in sources of nonstructural carbohydrate and crude protein. J. Dairy Sci. 73:1039-1050.

Chaney, A. L. and E. P. Marbach. 1962. Modified reagents for determination of urea and ammonia. Clin. Chem. 8:130-132.

Charles, S. L. 1999. Microsomal ethanol-oxidizing system (MEOS): The first 30 years (1968-1998) - A review. Alcohol. Clin. Exp. Res. 23:991-1007.

Cheng, K. J., C. W. Forsberg, H. Minato and J. W. Costerton. 1991. Microbial ecology and physiology of feed degradation within the rumen. In: Physiological Aspects of Digestion and Metabolism in Ruminant (Ed. T. Suda, Y. Sasaki and R. Kawashima), Academic Press, Toronto, ON. pp. 595-624.

Chumpawadee, S. and O. Pimpa. 2009. Effects of non forage fiber sources in total mixed ration on feed intake, nutrient digestibility, chewing behavior and ruminal fermentation in beef cattle. J. Anim. Vet. Adv. 8:2038-2044.

Church, D. C. 1972. Digestive physiology and nutrition of ruminants. In: Practical Nutrition. O \& B books Inc. Corvallis, Oregon, USA. 3:351.

Doumas, B. T., W. A. Watson and H. G. Biggs. 1971. Albumin standards and the measurement of serum albumin with bromocresol green. Clin. Chim. Acta. 31:87-96.

Farrance, I. 1987. Plasma glucose methods, a review. Clin. Chem. Rev. 8:55-68.

Flack, C. P. and J. W. Woollen. 1984. Prevention of interference by dextran with biurret type assay of serum. Clin. Chem. 30:559561.

Ellenberger, M. A., D. E. Johnson, G. E. Carstens, K. L. Hossener, M. D. Holland, T. M. Nett and C. F. Nockels. 1989. Endocrine and metabolic change during altered growth rates in beef cattle. J. Anim. Sci. 67:1446.

Erdman, R. A., G. H. Proctor and J. H. Vandersall. 1986. Effect of rumen ammonia concentration on in situ rate and extent of digestion of feedstuffs. J. Dairy Sci. 69:2312-2320.

Enright, W. J., J. F. Quirke, P. D. Gluckman, B. H. Breier, L. G. Kennedy, I. C. Hart, J. F. Rochecoert and P. Allen. 1990. Effects of long time administration of pituitary derived bovine growth hormone and estradiol on growth in steers. J. Anim. Sci. 68:2345.

Erkki, H., Y. Reino, R. Risto, V. Matti, H. Matti and S. Mikko. 1998. Effect of alcohol on exercise induced changes in serum glucose and serum free fatty acids. Alcohol. Clin. Exp. Res. p. 22.

Galbraith, H., D. G. Dempster and T. B. Miller. 1978. A note on the effect of castration on the growth performance and concentrations of some blood metabolites and hormones in British Fresian male cattle. Anim. Prod. 26:339-342.

Harrison, J. H., R. E. Riley and K. A. Long. 1989. Effect of type and amount of buffer addition to grass silage-based total mixed rations on milk production and composition. J. Dairy. Sci. 72:1824-1830.

Howard, K., N. Takusari and N. Yamagishi. 1986. Effect of TMR feeding frequency on eating behavior of lactating cow. J. Dairy Sci. 69:692-694.

Hristov, A. N. and T. A. McAllister. 2002. Effects of inoculants on whole-barley silage fermentation and dry matter disappearance in situ. J. Anim. Sci. 80:510-516.
Husdan, H. and A. Rapoport. 1968. Estimation of creatinine by the Jaffe reaction: a comparison of three methods. Clin. Chem. $14: 222-238$.

Keady, T. W. J. and C. S. Mayne. 2001. The effect of concentrate energy source on feed intake and rumen fermentation parameters of dairy cows offered a range of grass silage. Anim. Feed Sci. Technol. 90:117-129.

Kellems, R., O. R. Jones, D. Andrus and M. V. Wallentine. 1991. Effect of moisture in total mixed rations on feed consumption and milk production and composition in Holstein cows. J. Dairy Sci. 74:929-932.

Kim, K. H., K. S. Kim, S. C. Lee, Y. G. Oh, C. S. Chung and K. J. Kim. 2003. Effects of total mixed rations on ruminal characteristics, digestibility and beef production of Hanwoo. J. Anim. Sci. Technol. (Kor). 45:387-396.

Li, D. Y., J. Y. Ko, N. J. Choi, S. S. Lee, J. Y. Song, S. Y. Lee, S. H. Park, H. G. Sung and J. K. Ha. 2003a. Effects of types of TMR on rumen fermentation characteristics and nutrients digestibility in sheep. J. Anim. Sci. Technol. (Kor). 45:805-812.

Li, D. Y., S. S. Lee, N. J. Choi, S. Y. Lee, H. G. Sung, J. Y. Ko, S. G. Yun and J. K. Ha. 2003b. Effects of feeding system on rumen fermentation parameters and nutrient digestibility in Holstein steers. Asian-Aust. J. Anim. Sci. 16:1482-1486.

Lin, G. Z., C. H. Kim, S. J. Ohh, K. I. Sung, H. S. Kim, J. B. Kim and B. J. Hong. 2001. Effect of alcohol-fermented feedstuffs on growth performance and blood metabolites in hanwoo. J. Anim. Sci. Technol. (Kor.) 43:881-894.

Lin, G. Z., B. W. Kim, H. S. Kim, K. I. Sung, S. J. Ohh, B. J. Hong and J. S. Shin. 2004. Changes in serum metabolites and growth characteristics of Korean native steers fed alcohol-fermented feeds. Asian-Aust. J. Anim. Sci. 17:648-654.

Mandebvu, P., J. W. West, M. A. Froetschel, R. D. Hatfield, R. N. Gates and G. M. Hill. 1999. Effect of enzyme or microbial treatment of bermudagrass forage before ensiling on cell wall composition, end products of silage fermentation and in situ digestion kinetics. Anim. Feed Sci. Technol. 77:317-329.

Mao, S. Y., G. Zhang and W. Y. Zhu. 2007. Effect of disodium fumarate on in vitro rumen fermentation of different substrates and rumen bacterial communities as revealed by denaturing gradient gel electrophoresis analysis of 16S ribosomal DNA. Asian-Aust. J. Anim. Sci. 20:543-549.

McGilliard, M. L., J. M. Swisher and R. E. James. 1983. Grouping lactating cows by nutritional requirements for feeding. J. Dairy Sci. 66:1084-1093.

McCarthy, R. D., T. H. Klusmeyer, J. L. Vicini, J. H. Clark and D. R. Nelson. 1989. Effects of source of protein and carbohydrate on ruminal fermentation and passage of nutrients to the small intestine of lactating cows. J. Dairy Sci. 72:2002-2016.

Ministry of Agriculture and Forestry. 2002. Development of TMR feeding system for fattening Hanwoo. National Agricultural Co-operative Federation Stock Raising Research Institute and Agriculture-Life Science Department, Seoul National University, Seoul, Republic of Korea.

NIAS (National Institute of Animal Science). 2007. Standard tables of feed composition in Korea. Rural Development Administration (RDA), Republic of Korea.

Nock, J. E., R. L. Steele and D. G. Braund. 1985. Effect of mixed ration nutrient density on milk of cows transferred from high production group. J. Dairy Sci. 68:133-139. 
Nock, J. E., R. L. Steele and D. G. Braund. 1986. Performance of dairy cows fed forage and grain separately versus a total mixed ration. J. Dairy Sci. 69:2140-2147.

Overton, T. R., M. R. Cameron, J. P. Elliott, J. H. Clark and D. R. Nelson. 1995. Ruminal fermentation and passage of nutrients to the duodenum of lactating cows fed mixtures of corn and barley. J. Dairy Sci. 78:1981.

Owen, J. B. 1984. Complete-diet feeding for cattle. Livest. Prod. Sci. 11:269-285.

Park, B. K., J. M. Gil, J. B. Kim, B. J. Hong, C. S. Ra and J. S. Shin. 2003. Effects of fermented feedstuff with we brewer's grain and soybean on fattening performance and carcass grade in Hanwoo steers. J. Anim. Sci. Technol. (Kor.) 45:397-408.

Patterson, D. C., C. S. Mayne, F. J. Gordon and D. J. Kilpatrick. 1997. An evaluation of an inoculant/enzyme preparation as an additive for grass silage for dairy cattle. Grass Forage Sci. 52:325-335.

Roch-Ramel, F. 1967. An enzymic and fluorophotometric method for estimating urea concentrations in nanoliter specimens. Anal. Biochem. 21:372-381.

Russell, J. B. and P. J. Van Soest. 1984. In vitro ruminal fermentation of organic acids common in forage. Appl. Envron. Microbiol. 47:155-159.
Russell, J. B. and H. J. Strobel. 1988. Effects of additives on in vitro ruminal fermentation: A comparison of monensin and bacitracin, another gram-positive antibiotic. J. Anim. Sci. 66:552-558.

SAS Institute Inc. 2004. SAS/STAT user's guide version 9.1. Statistical Analysis System (SAS) Institute Inc., Cary, NC, USA.

Sasaki, H., K. Horiguchi and T. Takahashi. 2001. Effects of concentrate and roughage ratios on ruminal balance of long chain fatty acids in sheep. Asian-Aust. J. Anim. Sci. 14:960965.

Sirohi, S. K., M. Raman and T. K. Walli. 2001. Development and evaluation of protected fat in wheat straw based total mixed ration. Asian-Aust. J. Anim. Sci. 14:1405-1408.

Slyter, L. L., L. D. Satter and D. A. Dinius, 1979. Effect of ruminal ammonia concentration on nitrogen utilization by steers. J. Anim. Sci. 48:906-912.

Tilley, J. M. A. and R. A. Terry. 1963. A two-stage technique for the in vitro digestion of forage crops. Grass and Forage Sci. 18:104-111.

Van Soest, P. J., J. B. Robertson and B. A. Lewis. 1991. Methods of dietary fiber, neutral detergent fiber, and nonstarch polysaccharides in relation to animal nutrition. J. Dairy Sci. 74:3583. 